\title{
The first Eocene species of Bacanius (Coleoptera: Histeridae: Dendrophilinae) from Rovno amber
}

\section{Первый эоџеновый вид карапузиков рода Bacanius (Coleoptera: Histeridae: Dendrophilinae) из ровенского янтаря}

\author{
Alexander V. Sokolov' ${ }^{1}$, Evgeny E. Perkovsky ${ }^{2,3}$ \\ Александр В. Соколов ${ }^{1}$, Евгений Э. Перковский ${ }^{2,3}$
}

\footnotetext{
${ }^{1}$ Ltd. Service Aqua, Severniy bulvar, 12V, 84, Moscow 127490, Russia. E-mail: margarinotus@yandex.ru

${ }^{2}$ Schmalhausen Institute of Zoology, National Academy of Sciences of Ukraine, Bogdan Khmelnitsky Str. 15, Kiev 01601, Ukraine.

${ }^{3}$ A.A. Borissiak Paleontological Institute, Russian Academy of Sciences, Profsoyuznaya Str. 123, 117868 Moscow, Russia. E-mail: perkovsk@gmail.com

'ООО «Сервис Аква», Северный бульвар, 12в, 84, Москва 127490, Россия.

2 Институт зоологии им. И.И. Шмальгаузена НАН Украины, ул. Б. Хмельницкого, 15, Киев, 01030, Украина.

${ }^{3}$ Палеонтологический институт им. А.А. Борисяка РАН, ул. Профсоюзная 123, Москва, 117997, Россия.
}

KEY WORDS: clown beetles, Bacanius kirejtshuki, new species, Rovno amber.

КЛЮЧЕВЫЕ СЛОВА: карапузики, Bacanius kirejtshuki, новый вид, ровенский янтарь.

ABSTRACT. Description of new species of clownbeetles, Bacanius kirejtshuki sp.n. from Rovno amber, is given. It's first fossil Bacaniini and the first fossil species of microhisterid ecological group. The place of new species in the tribe is discussed.

РЕЗЮМЕ. Описывается новый вид Bacanius kirejtshuki sp.n. из ровенского янтаря. Это первый ископаемый карапузик трибы Васаniini и первый ископаемый представитель экологической группы микрогистерид. Обсуждается систематическое положение нового вида в трибе.

\section{Introduction}

Histeridae is relatively large family with eleven subfamilies and more than 4260 species [Mazur, 2011; Kovarik, Caterino, 2016]. They distributed in all terrestrial biomes except tundra, with maximal diversity in tropics. Toward the poles the number of species strongly decline (until 50-60 species in boreal forests). Clown beetles are very diverse morphologically and ecologically. Mostly they are predators that consume larvae of flies and xylobiont beetles in decaying substrates of animal and plant origin, under bark of trees. There is peculiar group associated with nests and burrows of mammals and birds. Inhabitants of ant's and termite's nests are various and specialized, two subfamilies of the obligate inquilines include more than 500 species. The diverse psammophilic species distributed in all desert's areas.
At present, 20 fossil histerid species are described [Heer, 1862; Theobald, 1935; Chatzimanolis et al., 2006; Caterino et al., 2015; Caterino, Maddison, 2018; Poinar et al., 2009; Alekseev, 2016; Degalier et al., 2019; Zhou et al., 2019; Jiang et al., 2020]. Several extinct species are reported, but not described [Klebs, 1910, Duncan et al., 1998]. Systematical position of some species in taxonomical system of the family is disputable. The earliest them belong to mid-Cretaceous (Burmese amber), the later of the remains from different ages before the Pliocene. The species described below belongs to nominative genus of Bacaniini. It includes 158 species, of which about five sixth are from tropical regions. Bacaniini are very small beetles with uniform habitus, belonging to the ecological group of microhisterids. They inhabit trees of varying degrees of decomposition and decaying vegetation, more than 10 troglobionts are described (nearly half of its in subtropical regions), some species are collected in nests of ants and termites. Most of them feed on fungal spores [Kovarik, Caterino, 2016]. Fossil representatives of the tribe never have been named; one specimen was determined as Bacanius? by Edmund Reitter [Klebs, 1910], but the collection of Klebs was mostly lost in the time of Second World War.

\section{Material and methods}

Illustrations were prepared with digital camera Canon EOS 6d and microscope Zeiss AxioScope A1. Measurements are abbreviated as follows: PEL — length

How to cite this article: Sokolov A.V., Perkovsky E.E. 2020. The first Eocene species of Bacanius (Coleoptera: Histeridae: Dendrophilinae) from Rovno amber // Russian Entomol. J. Vol.29. No.2. P.157-160. doi: 10.15298/ rusentj.29.2.06 
between anterior angles of pronotum and apices of elytra, PL - pronotal length, EL - length of elytron along suture line, APW - pronotal width across anterior angles, PPW — width between posterior angles of pronotum, EW - maximal width between outer margins of elytra, $\mathrm{H}$ - distance from metaventrite to maximal high of elytra, measured in lateral position. Num- bers in brackets equal the distances between punctures (in their diameters). The piece was mined in Rovno region, most probably in Klesov or Vladimirets and Zarechnoje districts [see Martynova et al., 2019], e.g. Veselukha floodplaine [see Lyubarsky, Perkovsky, 2020]. Holotype is housed in the amber collection of the I.I. Schmalhausen Institute of Zoology, Kiev (SIZK).
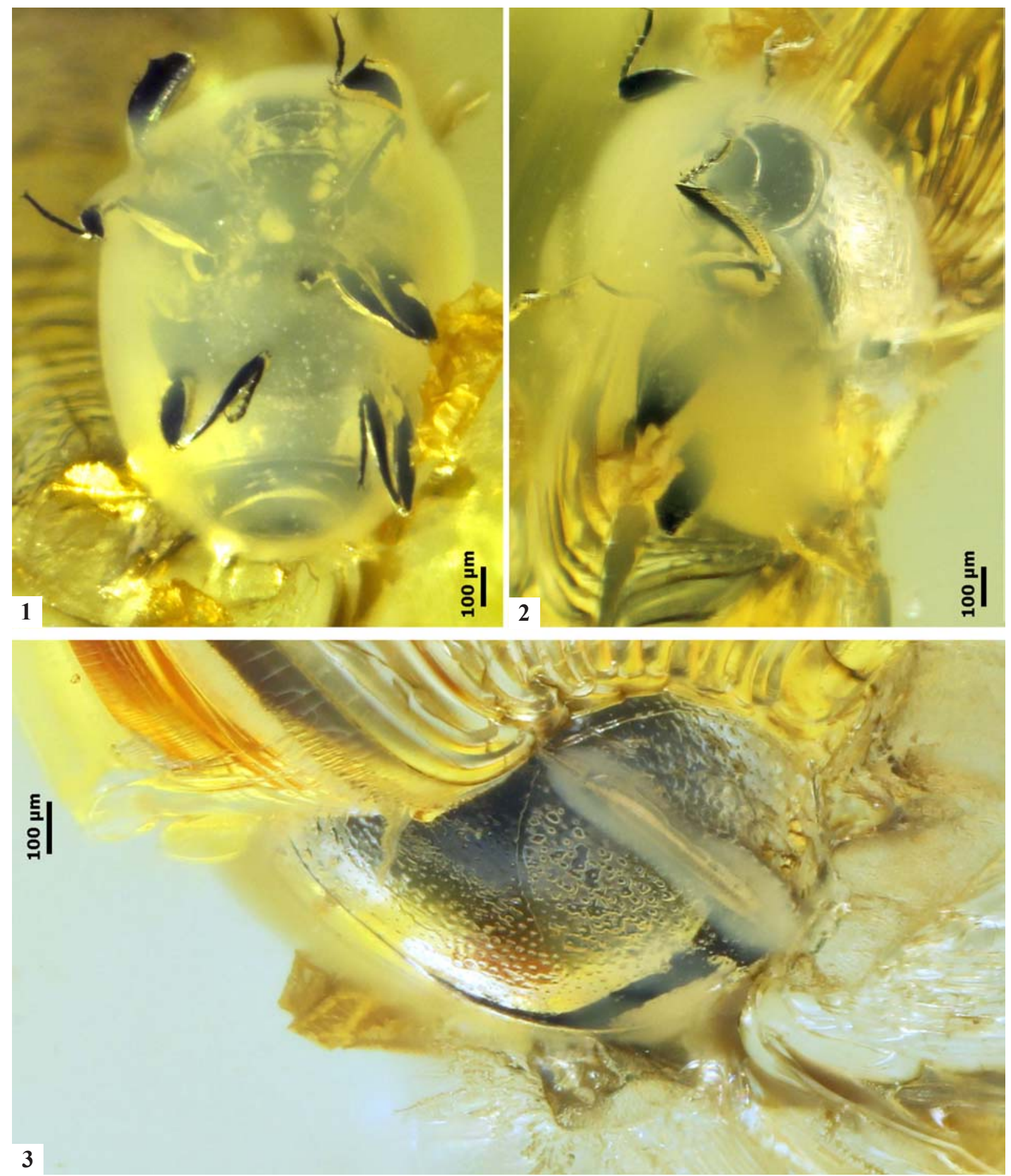

Figs 1-3. Bacanius kirejtshuki sp.n.: 1, 3 - habitus, ventral and dorsal view; 2 - head, lateral view. Рис. 1-3. Bacanius kirejtshuki sp.n.: 1, 3 - габитус, снизу и сверху; 2 - голова, сбоку. 
Systematic paleontology

Family Histeridae Gyllenhal, 1808

Subfamily Dendrophilinae Reitter, 1909

Tribe Bacaniini Kryzhanovskij, 1976

Genus Bacanius J.L. LeConte, 1853

Bacanius kirejtshuki Sokolov et Perkovsky, sp.n. Figs 1-5.

MATERIAL. Holotype SIZK UA-28067.

DESCRIPTION. Habitus as illustrated (Figs 1-5). PEL = $1.2 \mathrm{~mm} . \mathrm{H}=0.6 \mathrm{~mm}$. Colour dark brown. Dorsal surface without microsculpture. Broadly oval, moderately convex. Widest at elytral humeri. Head retracted in thorax, relatively big, form typical for the tribe Bacaniini (Figs 2, 4). Frons and epistoma with uniform punctures coarse and sparse (2-3). Frons separate from epistoma by distinct stria, arcuate inwardly to vertex. First antennal segment poorly distinguishable, rest parts of antenna retracted in thorax.

$\mathrm{PL}=0.38 \mathrm{~mm} . \mathrm{PPW}=0.9 \mathrm{~mm} . \mathrm{APW}=0.8 \mathrm{~mm} . \mathrm{PPW}=$ $0.9 \mathrm{~mm}$. Small part of pronotum visible only, impossible define features of punctures on the disc (Figs 2, 4). Lateral surface with fine and sparse (2-4) punctures. Marginal pronotal stria complete laterally and anteriorly. Antescutellar stria absent. Scutellum not visible.

$\mathrm{EW}=1.0 \mathrm{~mm}$. Elytral punctures fine and sparse (2-4), distinguishable partly from middle to apex. Impossible to descern punctures in basal part of elytra and along suture. Outer subhumeral stria well impressed, complete, prolong to base. Epipleural stria distinct, situated closer to subhumeral striae. Prosternal lobe broad and prominent, with conspicuous sparse punctures (Figs 1, 5). Mesometasternal suture looks like line of coarse punctures. Punctures of meso- and metasternum invisible mostly. Lateral parts of metasternum with various punctures, relatively dense (1.0-1.5). Hind edge of metaventrite arcuate to abdomen. There are outer and inner striae of 1 st abdominal ventrite. Its surface coarsely punctured laterally and along anterior margin, rest part finely punctured. Probably pygidium smooth or with very weak punctures.

Legs of typical form for Bacaniini. Foretibia broadened with unique tooth near distal angle. Mesotibia and metatibia narrowed, not strongly broadened apically, mesotibia only with several fine spurs on the apex.

COMPARATIVE REMARKS. The described species belongs to Bacaniini by not truncate elytra that covered exposed tergites, dorsal striae absent. Generic system of Bacanius is developed not so good now, many extant genera of Bacaniini consist with species of former Bacanius sensu stricto. Nonetheless new species has all key characters for attribute it to genus Bacanius. In 1984 Slawomir Mazur established subgenus Gomyister Mazur, 1984, distributed mostly in tropical areas of the Old and New World [Mazur, 1984]. They can be recognized by complete subhumeral stria and absence of antescutellar stria. Bacanius kirejtshuki has that features, so we suppose to place it close to recent Gomyister.

ETYMOLOGY. The new species is dedicated to coleopterist Dr. Sc. Alexander G. Kirejtshuk.

\section{Discussion}

Among 158 species of the tribe Bacaniini only 13 species reach the regions with the warm temperate climate [Mazur,
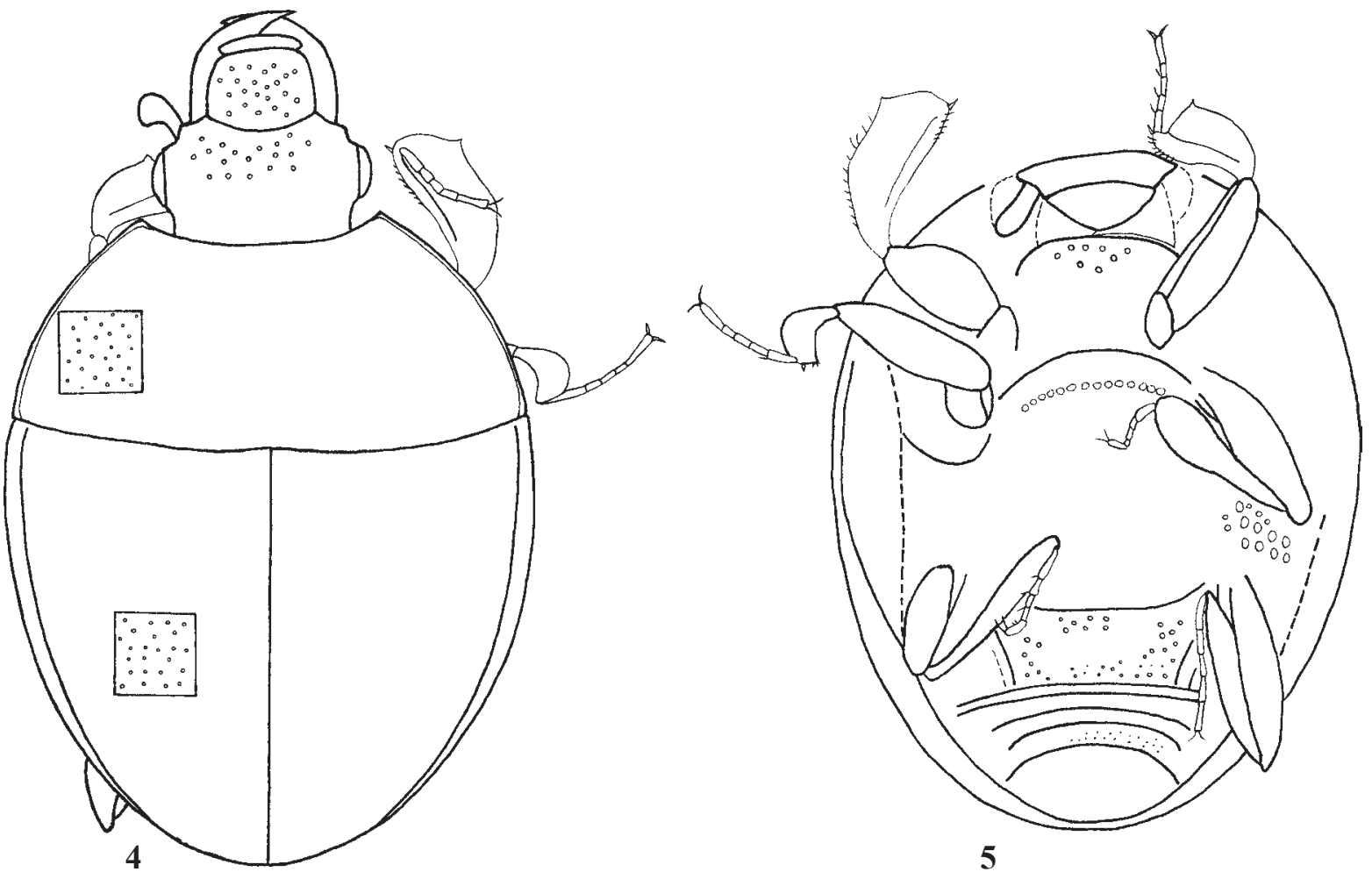

Figs 4-5. Bacanius kirejtshuki sp.n., habitus: 4 - dorsal view; 5 - ventral view.

Рис. 4-5. Bacanius kirejtshuki sp.n., габитус: 4 - сверху; 5 - снизу. 
2011]. Moreover, five sixth of all these species are restricted by tropical regions in the distribution. Thus, with high probability we can assign the new species to a group of taxa which had the northern distribution boundary at the late Eocene lying along the southern coast of the Subparathetys [Perkovsky, 2018; Dubovikoff et al., 2020; Legalov et al., 2018, 2019, and references therein]. Many thermophile insects have the same northern boundary of the distribution. It explains the absence of species shared by both, Rovno and Baltic amber, within the families of the Rovno amber fauna with high portion of the thermophile taxa, e.g. among 14 bethylid species registered in Rovno amber one species only from extant Chilean genus Lytopsenella Kieffer, 1911 was recorded also in the Baltic amber [Perkovsky, 2018; Colombo et al., 2020; our unpublished data], and many of these bethylid genera are strongly thermophile [Colombo et al., 2020].

Acknowledgements. We wish to thank Prof. Kirill V. Makarov (Moscow State Pedagogical University, Moscow, Russia) for help with making photographs, to Anatoly P. Vlaskin (SIZK) for selecting and polishing of the specimen. Special thanks are due to Dr. Ives Gomy (Nevers, France) for advices about systematic position of this clown beetle.

\section{References}

Alekseev V.I. 2016. Description of two clown beetles (Coleoptera: Staphyliniformia: Hydrophiloidea: Histeridae) from Baltic amber (Cenozoic, Paleogene, Eocene) // Baltic Journal of Coleopterology. Vol.16. No.1. P. 27-35.

Caterino M.S., Maddison D.R. 2018. An early and mysterious histerid inquiline from Cretaceous Burmese amber (Coleoptera, Histeridae) // ZooKeys. Vol.733. P.119-129.

Caterino M.S., Wolf-Schwenninger K., Bechly G. 2015. Cretonthophilus tuberculatus, a remarkable new genus and species of hister beetle (Coleoptera: Histeridae) from Cretaceous Burmese amber // Zootaxa. Vol.4052. P.241-245.

Chatzimanolis S., Caterino M. S., Engel M. S. 2006. The first fossil of the subfamily Trypanaeinae (Coleoptera: Histeridae): a new species of Trypanaeus in Dominican amber // Coleopterists' Bulletin. Vol.60. P.333-340.

Colombo W.D., Gobbi F.T., Perkovsky E.E., Azevedo C.O. 2020 Synopsis of the fossil Pristocerinae (Hymenoptera, Bethylidae) with description of two new genera and six species from Burmese, Taimyr, Baltic and Rovno ambers // Historical Biology. DOI: $10.1080 / 08912963.2020 .1733551$.

Degalier N., Garrouste R., Nel A. 2019. New and poorly known Cenozoic clown beetle compressions from France (Insecta: Coleoptera: Histeridae) // Annales de la Société entomologique de France (N.S.). Vol.55. No.6. P.471-481.

Dubovikoff D.A., Dlussky G.M., Perkovsky E.E., Abakumov E.V. 2020. A new species of the genus Protaneuretus Wheeler
(Hymenoptera, Formicidae) from Bitterfeld amber(Late Eocene), with a key to the species of the genus // Paleontologicheskii Zhurnal. No.4. P.67-69 [in Russian, translated: Paleontological Journal. Vol.54. No.4. in press].

Duncan I.J., Briggs D.E.G., Archer M. 1998. Three-dimensionally mineralized insects and millipedes from the Tertiary of Riversleigh, Queensland, Australia // Palaeontology. Vol.41. P.835851 .

Heer O. 1862. Beitrage zur Insektenfauna Oeningens. ColeopteraGeodephagen, Hydrocanthariden, Gyriniden, Brachelytren, Clavicornen, Lamellicornen und Buprestiden. Natuurkundige Verhandelingen van de Hollandsche maatschappij der Wetenschappen te Haarlem. Ser.2. Vol.16. S.1-90.

Jiang R., Song W., Yang H., Shi C., Wang S. 2020. Discovery of the first Onthophilus species from mid-Cretaceous Burmese amber (Coleoptera: Histeridae) // Cretaceous Research. Vol.111. 104443. https://doi.org/10.1016/j.cretres.2020.104443.

Klebs R. 1910. Über Bernsteineinschlüsse in allgemeinen und die Coleopteren meiner Bernsteinsammlung // Schriften der Physikalisch-ökonomischen Gesellschaft zu Königsberg. Bd.51. H.3. S.217-242.

Kovarik P., Caterino M.S. 2016. Histeridae Gyllenhal, 1808 // R.G. Beutel, R.A.B. Leschen (eds.). Handbook of zoology. Pt.38. Coleoptera. Vol.1. Morphology and Systematics. 2nd ed. Berlin: Walter De Gruyter. P.281-314.

Legalov A.A., Nazarenko V.Yu., Perkovsky E.E. 2018. A new genus of fungus weevils (Coleoptera: Anthribidae) in Rovno amber // Fossil Record. Vol.21. P.207-212.

Legalov A.A., Nazarenko V.Yu., Perkovsky E.E. 2019. New weevils (Coleoptera: Curculionidae) from Rovno amber // Paleontol. J. Vol.53. No.10. P.1045-1059.

Lyubarsky G.Yu., Perkovsky E.E. 2020. First Rovno amber species of the genus Telmatophilus (Coleoptera: Clavicornia: Cryptophagidae) from Veselukha floodplain // Invert. Zool. Vol.17. No.1. P.25-35. doi: 10.15298/invertzool.17.1.03.

Martynova K.V., Perkovsky E.E., Olmi M., Vasilenko D.V. 2019. New records of Upper Eocene chrysidoid wasps (Hymenoptera: Chrysidoidea) from basins of Styr and Stokhod rivers (Rovno amber) // Paleontol. J. Vol.53. No.10. P.998-1023.

Mazur S. 1984. A world catalogue of Histeridae // Polskie Pismo Entomologiczne. Vol.54. Nos 3-4. P.1-376.

Mazur S. 2011. A concise catalogue of the Histeridae (Insecta: Coleoptera). Warsaw: Warsaw University of Life Sciences SGGW Press. 332 p.

Perkovsky E.E. 2018. Only a half of species of Hymenoptera in Rovno amber is common with Baltic amber // Vestnik Zoologii. Vol.52. P.353-360.

Poinar G., Brown A.E. 2009. Pantostictus burmanicus, a new genus and species of Cretaceous beetles (Coleoptera, Hydrophiloidea, Histeridae) in Burmese amber // Proceedings of the Entomological Society of Washington. Vol.111. P.38-46.

Theobald N. 1935. Taxonomic names, in La faune entomologique des gisements Mio-Pliocenes du Massif Central // Revue des Sciences Naturelles d'Auvergne (N.S.). Vol.1. P.65-104.

Zhou Y.-L., Slipinski A., Ren D., Parker J. 2019. A Mesozoic clown beetle myrmecophile (Coleoptera: Histeridae) // eLife. Vol.8. P.1-14. 